\title{
Productivity Study of Komatsu Pc 2000 Excavator Tools B0 and B20 Fuel in the Mining Area of PT. Bukit Asam Tbk Tanjung Enim South Sumatra
}

\author{
Fitri Aldena \\ \{ $710015118 @$ Student.itny.ac.id \} \\ Department of Mining Engineering Faculty of Mineral Technology Yogyakarta National \\ Institute of Technology Yogyakarta, Indonesia

\begin{abstract}
To support underground mining activities, good and effective ground support is needed. The coal production target at the mining site in May 2019 for the production target set in one Komatsu PC 2000 fleet is 1,115,836 tons / hour. From the results of the calculations done, the actual productivity for the PC 2000 is 776.086 tons / hour. The cause of the actual productivity of the equipment used has not reached the production target is due to work constraints which cause the effective working time of the tools to be low and the MA value of the tools that is not good. To increase the productivity of each piece of equipment, it can be done by reducing the time constraints that can be avoided such as delays in work, leaving early, resting too quickly and starting late after rest in order to increase the effective working time of the equipment. The minimum fuel consumption of B20 biodiesel is lower than diesel fuel, which is $84 \mathrm{~kg} /$ hour compared to $92 \mathrm{~kg} /$ hour of diesel fuel. The average torque of diesel fuel is $423.4 \mathrm{~kg} . \mathrm{m}$ and the average torque of B-20 biodiesel fuel is $400.3 \mathrm{~kg} . \mathrm{m}$.
\end{abstract}

Keywords: Underground Mine, Komatsu PC 2000, production target

\section{Introduction}

PT Bukit Asam Tbk is a state-owned company engaged in coal mining, located in Lawang Kidul District, Muara Enim Regency, South Sumatra Province. Currently, PT Bukit Asam Tbk is mining in three locations, namely the Air Laya Mine (TAL), Muara Tiga Besat Utara (MTBU), and Banko.

\section{Research Method}

The In this research, it is intended to retrieve and collect data related to the productivity of the Komatsu PC 2000 Excavator with PC 1250 on B0 and B20 fuels in the mining work area. Therefore this research was conducted to determine the productivity of the Komatsu PC 2000 
Excavator, including : Literature studies are carried out by studying supporting library materials obtained from books on Mechanical Soil Transfers (Indonesianto, 2019 Projosumarto, 1993; Tenriajeng, 2003) looking for supporting libraries, including: Literature from the library. Supporting seminar paper. Company information. PTMK hand book Field research was carried out in several stages of activity: Surface geological surveys, by making direct observations of the surface geology and seeking supporting information relating to the issues to be discussed. Determining the location of the observation site including the sampling location for observations in certain areas that can represent the whole problem so that the research data can be used accordingly. Adjusting to the formulation of the problem aims to make the research carried out not to expand and the data taken to be used effectively. The data collected is divided into two, namely primary data and secondary data. The data included in the primary data include:. PC 2000 Cycle Time Time \& Type of Obstacle, Fuel consumption per hour Field Documentation Photos The data included in secondary data, among others : Machine specifications Unit availability Record down time Engine torque Map of research locations. Data processing is done by several calculations and depictions. Furthermore, analysis of working hours, planned and actual productivity, tables and graphs of comparison of fuel consumption of B0 and B20, tables and graphs of comparison of engine torque using B0 and B20 fuels. Obtained after doing the correlation between the results of data processing that has been done with the problem under study.

\section{Result}

\section{A. Research Location}

Observation of the use of effective working time is prioritized on loading and transportation activities.

Table 1 Effective Working Time

\begin{tabular}{ccc}
\hline Tool's name & Code & Effective Time (Hours / month) \\
\hline Komatsu PC 2000 & EX 1751 & 530 \\
\hline
\end{tabular}

The productivity of the actual excavator and dump truck can be determined by calculating the actual productivity by including the factors that affect productivity.

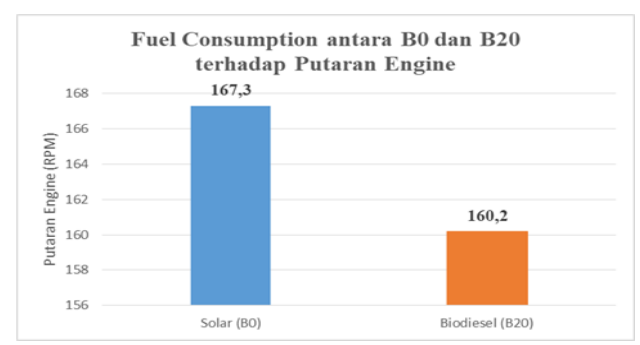

Figure 1 Comparison Graph of Average Fuel Consumption 
The average fuel consumption for diesel fuel is $167.3 \mathrm{~kg} /$ hour and biodiesel fuel B20 is $160.2 \mathrm{~kg} /$ hour, so it can be concluded that the fuel consumption of diesel engine SAA12V140E-3 using diesel fuel is higher than biodiesel fuel B20.

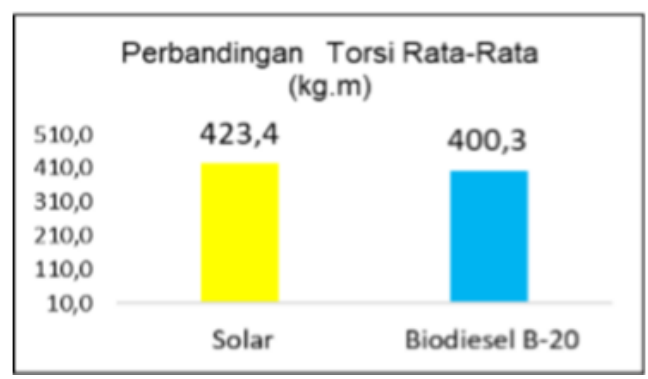

Figure 2 Average Torque Comparison Graph

From the graphic image, the comparison of torque and average torque can be seen, for the maximum torque of diesel fuel is $500 \mathrm{~kg} . \mathrm{m}$ and the maximum torque of biodiesel fuel B-20 is $485 \mathrm{~kg} . \mathrm{m}$. Meanwhile, the average torque of diesel fuel is $423.4 \mathrm{~kg} . \mathrm{m}$ and the average torque of B-20 biodiesel fuel is $400.3 \mathrm{~kg} . \mathrm{m}$. So it can be concluded that the torque of the diesel engine SAA12V140E-3 using diesel fuel is higher than biodiesel fuel B-20. In mining activities, it must be adjusted to the existing production target of PT. Bukit Asam Tbk, has different production targets in one fleet of equipment use, for the productivity target set in one Komatsu PC 2000 fleet of $1,115,836$. From the results of observations made in the field, the actual existing production is not in accordance with the target set by the company.

Table 1 Actual Productivity of Load Tools

\begin{tabular}{ccc}
\hline No. & Tool & Actual Production (Ton / Hour) \\
\hline 1 & Komatsu PC 2000 & 776,086 \\
\hline
\end{tabular}

From improvements to effective working time will result in increased work efficiency so that the resulting production is even greater.

Table 2 Increased work efficiency and MA

\begin{tabular}{cccc}
\hline Unit & $\begin{array}{c}\text { current work } \\
\text { efficiency }\end{array}$ & $\begin{array}{c}\text { work efficiency after being } \\
\text { improved }\end{array}$ & $\begin{array}{c}\text { MA After Increased } \\
\text { Effective Working Time }\end{array}$ \\
\hline $\begin{array}{c}\text { Komatsu PC } \\
\mathbf{2 0 0 0}\end{array}$ & $84 \%$ & $92 \%$ & $96 \%$ \\
\hline
\end{tabular}


The productivity of the digging and loading equipment after being increased can be seen in table 3 :

Table Actual Productivity of Load Digging Equipment after Increased

\begin{tabular}{lll}
\hline Tool & $\begin{array}{l}\text { Actual Productivity } \\
\text { (Tons / Hour) }\end{array}$ & $\begin{array}{l}\text { Productivity after repair (tonnes / } \\
\text { hour) }\end{array}$ \\
\hline Komatsu PC 2000 & 776,086 & $1.420,237$ \\
\hline
\end{tabular}

Production of normal loading and digging equipment is approaching the coal production target in May 2019 after an increase. This shows that the production of digging and loading equipment has increased but productivity cannot exceed theoretical productivity because it is taken from the maximum calculation of the capabilities of these tools. From the results of observations made in the field that there is no significant effect on the use of diesel fuel types B0 and B20 because at the time of use it does not have a significant effect on the MA tools and PA tools because at the time of the study there was no tool repair due to engine failure and it was in accordance with the usage data. existing tools at PT. Bukit Asam amTbk already uses B20 type fuel for existing loading and transportation equipment. The maximum torque for diesel fuel is $500 \mathrm{~kg} . \mathrm{m}$ and the maximum torque for B-20 biodiesel fuel is $485 \mathrm{~kg} . \mathrm{m}$. Meanwhile, the average torque of diesel fuel is $423.4 \mathrm{~kg} . \mathrm{m}$ and the average torque of B-20 biodiesel fuel is $400.3 \mathrm{~kg} . \mathrm{m}$. So it can be concluded that the torque of the diesel engine SAA12V140E-3 using diesel fuel is higher than biodiesel fuel B-20.

So for a decrease in torque on the performance of the diesel engine SAA12V140E-3 fueled by biodiesel B-20 by $3 \%$ and a decrease in the average torque on the performance of the diesel engine SAA12V140E-3 fueled by biodiesel B-20 by $5.4 \%$.

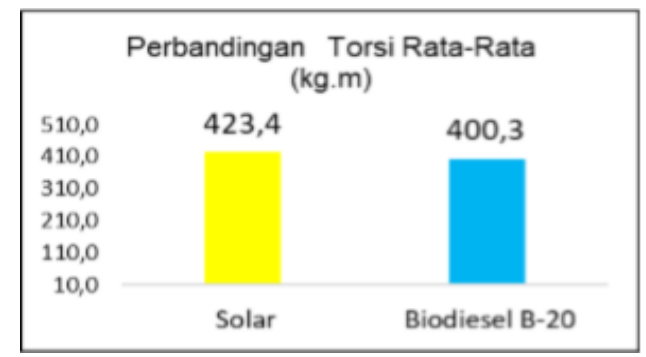

Figure 5.1 Average Torque Comparison Graph

\section{Conclusion}

From the results of research conducted, analysis and discussion of coal production activities at PT. Bukit Asam Tbk, it can be concluded that: The coal production target at the mining site in 
May 2019 for the production target set in one Komatsu PC 2000 fleet is 1,115,836 tons / hour From the results of the calculations done, the actual productivity for the PC 2000 is 776.086 tons / hour. The cause of the actual productivity of the equipment used has not reached the production target is because there are work obstacles that cause the effective working time of the tools to be low and the MA value of the tools is not good. To increase the productivity of each piece of equipment, it can be done by reducing the time constraints that can be avoided such as delays in work, leaving early, resting too quickly and starting too late after a break in order to increase the effective working time of the equipment. The minimum fuel consumption of B20 biodiesel is lower than diesel fuel, namely $84 \mathrm{~kg}$ / hour compared to $92 \mathrm{~kg}$ / hour. The average torque of diesel fuel is $423.4 \mathrm{~kg} . \mathrm{m}$ and the average torque of biodiesel fuel B-20 is $400.3 \mathrm{~kg} . \mathrm{m}$. So it can be concluded that the torque of the diesel engine SAA12V140E-3 using diesel fuel is higher than biodiesel fuel B-20.

\section{References}

[1.] Director General of Oil and Gas, "Decree No. 28 K / 10 / DJM.T / 2016 concerning the Second Amendment to the Decree of the Director General of Oil and Gas Number 3675 K / 24 / DJM / 2006

[2.] Concerning Standards and Quality of Domestic Type of Diesel Fuel Oil, ”2016

[3.] Partanto, Projosumarto. 1995. Mechanical Soil Transfers. Ministry of Mines, Bandung Institute of Technology. Bandung.

[4.] ......., 2010. "Caterpillar Performance Handbook", Edition 40, Caterpillar, Printed in USA.

[5.] ........, 2000. "Handbook of Ripping”, Edition 12, Caterpillar, Printed in USA.

[6.] ........, 2015. Detailed Exploration Work Unit. PT. Bukit Asam, Tbk.

[7.] ........, 2015. Civil and Hydrology Planning Work Unit. PT. Bukit Asam, Tbk.

[8.] ........, 2007. "Spesification \& Application Handbook", Edition 28, Komatsu, Printed in Japan. 